Regina Egetenmeyer (ed.)

\title{
Adult Education and Lifelong Learning in Europe and Beyond
}

Comparative Perspectives from the 2015 Würzburg Winter School

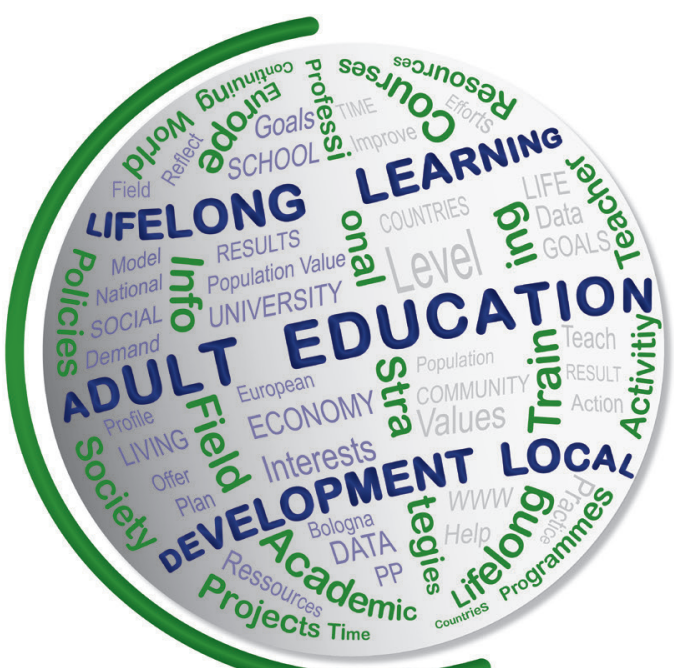


Regina Egetenmeyer (ed.)

\section{Adult Education and Lifelong Learning in Europe and Beyond}

Comparative Perspectives from the 2015

Würzburg Winter School 
Bibliographic Information published by the Deutsche Nationalbibliothek The Deutsche Nationalbibliothek lists this publication in the Deutsche Nationalbibliografie; detailed bibliographic data is available in the internet at http://dnb.d-nb.de.

This project has been funded with support from the German Federal Ministry of Education and Research (grant number: 01JG1510) and the Human Dynamics Centre of the Faculty of Human Sciences at the University of Würzburg. This publication reflects the views of the author only, and the German Federal Ministry of Education and Research as well as the Human Dynamics Centre cannot be held responsible for any use which may be made of the information contained therein.
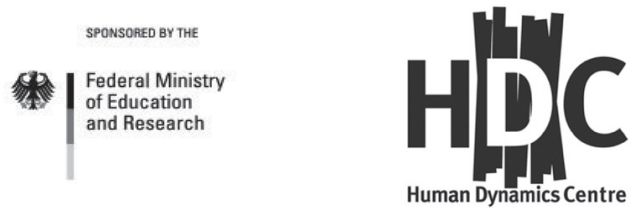

Proofreading: Carsten Bösel (consultUS)

Translation and Proofreading of Lima, Guimarães \& Touma: Helena Araújo (línguafranca)

Cover illustration: Beate Derra (University of Würzburg)

ISSN 0934-3695

ISBN 978-3-631-66635-7 (Print)

E-ISBN 978-3-653-05973-1 (E-Book)

DOI 10.3726/978-3-653-05973-1

(C) Peter Lang $\mathrm{GmbH}$

Internationaler Verlag der Wissenschaften

Frankfurt am Main 2016

All rights reserved.

Peter Lang Edition is an Imprint of Peter Lang GmbH.

Peter Lang - Frankfurt am Main · Bern · Bruxelles · New York · Oxford · Warszawa $\cdot$ Wien

All parts of this publication are protected by copyright. Any utilisation outside the strict limits of the copyright law, without the permission of the publisher, is forbidden and liable to prosecution. This applies in particular to reproductions, translations, microfilming, and storage and processing in electronic retrieval systems.

This publication has been peer reviewed.

www.peterlang.com 


\section{Table of Contents}

Bernd Käpplinger \& Steffi Robak

Preface

Regina Egetenmeyer

Comparing Adult Education and Lifelong Learning in

Europe and beyond: An Introduction

\section{Comparing Policies in Lifelong Learning}

Licínio C. Lima, Paula Guimarães \& Nathalie Touma

Adult learning and education policies in Germany, Portugal and Sweden:

An analysis of national reports to CONFINTEA VI

Chetan Singai, Gaia Gioli, Eva Riemer, Kapil Dev Regmi,

Sofia Mastrokoukou \& Shalini Singh

Knowledge economy and demographic change: Comparative case study of Europe and South Asia

\section{Comparing Professionalisation in Adult and Continuing Education}

Verena Liszt, Mina Toko \& Xiaojn Yan

Adult education and its key actors in academic professionalisation a comparison between China, India and the European Union

Vanna Boffo, Kathrin Kaleja, Khulud Sharif-Ali

\& Joana Fernandes

The curriculum of study programmes for adult educators -

the study cases of Italy, Germany and Portugal

Vanna Boffo, Kathrin Kaleja \& Joana Fernandes

Regulations and working conditions for trainers in adult education:

A comparative glance 
Franziska Semrau, Nataliya G. S. Vieira \& Elisa Guida Academic professionalisation in adult education: insights into study programmes in Germany, Italy and Portugal.

\section{Comparing Participation in adult Education}

Rute Ricardo, Bani Bora, Fabio Camilloni, Loretta Lizon, Mariana Cavaca, Prachi Sinha, Pratibha Kandera, Regina Egetenmeyer Participation and non-participation in adult education and learning: A comparative study between Portugal, Italy, Hungary, and India

\section{Comparing Quality Management}

Lisa Hilbig, Sabrina Thom \& Silvia Tursi

Comparing Quality Management Systems and procedures in Italy and Germany

Peggy Everett \& Christian Müller

Comparative analysis of two quality management models in the U.S.A. and Germany

\section{Comparing Guidance and Counselling in Lifelong Learning}

Nicoletta Tomei, Beatrice Carp \& Stefanie Kröner

Guidance and counselling in higher education: A comparison

between the career services in Germany and Italy.

Maria Grasso, Nicoletta Tomei, Laura Balázs, Deepak Goswami \& Bruna da Silva Ribas

Guidance and counseling: processes, methods and activities in a Lifelong perspective

\section{Country Reports}

Nicoletta Tomei

A regional perspective on tutorship as a potential

lifelong and adult guidance tool 


\section{Shalini Singh}

India towards a knowledge economy: Alternatives for the global

demographic challenge and inclusive development in India.

Kapil Dev Regmi

The status of adult literacy and lifelong learning in Nepal 
Licínio C. Lima, Paula Guimarães \& Nathalie Touma

\title{
Adult learning and education policies in Germany, Portugal and Sweden: An analysis of national reports to CONFINTEA VI
}

\begin{abstract}
The chapter presents a theoretical proposal of three analytical models of Adult Learning and Education (ALE) policies. Some analytical categories and the corresponding dimensions are organised according to the ALE rationale which is typical of each social policy model. Historical, cultural and educational features are mentioned in connexion with the different policy models and its interpretative capacity to making sense of policies and practices implemented in Germany, Portugal and Sweden. The analysis includes the states of the art and the official representations of ALE produced by the respective national authorities through national reports which were presented to CONFINTEA VI (2009).
\end{abstract}

\section{Introduction}

The analysis of adult learning and education (ALE) policies is a complex task, but it is crucial to understanding the multitude of supranational guidelines, governmental measures, strategies of public and private organisations, educational practices developed by schools, educational centres, social movements and civil society organisations, in addition to the study of certain individual lifelong learning dynamics.

Whenever we study educational reforms, priorities and objectives, projects and activities, ALE methods and practices in national and local, organisational or micro level contexts it is impossible to escape from certain core questions: What ALE conceptions are present? What are the priorities and goals to achieve? What are the most important concepts, methods of education, forms of organisation, administration and financing? What are the teaching methods, and who are the target groups and participants in educational activities? And on what grounds are they these and not others? Why is there not always consensus on these options? What are the dominant approaches and interests at national, local and international level? Who has the power to shape the educational guidelines that are followed by most national, regional and local governments? Why is public funding available for certain ALE activities but not for others? What are the most influential international and supranational organisations and how do they build and spread 
their political agendas for ALE? What is the role of the state, civil society and the market in developing the policies and practices of ALE?

Considering that learning and education are cultural, socially constructed phenomena, its political nature, i.e. its politicity, is always based on worldviews, on choices that depend on certain agendas and certain interests. Even when, as now, the consensus seems evident and is apparently shared worldwide, resulting in ALE policy guidelines we call hegemonic or dominant guidelines, there are always other possibilities, divergent interests, alternative projects. There is always political activity (politics), not only in the state context but also dependent on different conceptions of the role of the state in social policies. This political action gives rise to decisions and choices that are then translated into legislation, programmes and measures, educational conceptions and learning modes, forms of regulation and provision of education we generically call education policy.

This means that ALE policies always result from discourses and practices, guidance and actions, the global setting of priorities and rules not only located in the transnational and supranational level (mega level) and national level (macro level), but also in concrete organisational contexts (meso level) and even through different forms of reception and action in small contexts of social interaction (micro level). Although the available resources, authority and power differ widely between these levels of analysis, levels whose scale is at a lower level, are certainly affected but not fully determined by the higher levels. The learning and education of individuals in specific contexts of social action is always influenced by the decisions of the most powerful political and institutional actors, but it is never a simple copy or perfect reproduction of these influences.

There are contextual, cultural, educational and other circumstances that can facilitate the exercise of margins of relative autonomy by states, organisations, social groups and individuals. The study of policies in action, of the recontextualisation of political decisions in different social contexts and of any distinct educational appropriations already requires empirical studies. It requires analysis of actors and educational activities in specific social contexts, which, while of great relevance in the investigation of policies and practices, is not, however, the purpose of this chapter.

This chapter will briefly introduce some analytical models of ALE social policies that can support the interpretation of the action developed by international institutions (such as the United nations Educational, Scientific and Cultural Organisation - UNESCO), by supranational actors (like the European Union - EU), or by national and regional governments, public and private organisations and others. We shall only use the proposed analytical models to interpret some policy 
documents produced by government agencies from three countries of the EU that sought to offer a "state of the art" of ALE for presentation at the International Conference on Adult Education (CONFINTEA VI) organised by UNESCO in 2009 in Brazil, in the city of Belém do Pará. This does not mean that the theoretical proposals presented here are not useful for the analysis of concrete ALE actions and models and lifelong education practices, just that this task would not be possible within the objectives and limits of this text.

\section{Analytical models of adult learning and education}

The theoretical proposals that are presented here have their origin in research work that was initially developed by Lima (2005) and the subject of several courses in universities in Germany and other European and Latin American countries. This research work, as well as the accumulated teaching experience, were later resumed and deepened. In this process of review and academic development, which was incorporating other authors and other theoretical approaches, the doctoral work of Guimarães (2011) is emphasised, and this led the two authors to present an integrated joint proposal on analytical models for ALE social policies (Lima \& Guimarães 2011). The authors have subsequently published analytical work on ALE policies, including a historical interpretation of the Portuguese situation from the democratic revolution of 1974 to the present day (Lima \& Guimarães, 2015), an analysis of certain shorter historical periods, and government programmes developed in recent years in Portugal (Guimarães, 2013; Lima 2013). They have also directed courses and seminars in various countries and have developed educational tools on the interpretation of ALE policies in various national and international contexts. With another author they also produced a preliminary analysis and comparative policy documents on the participation of EU countries in CONFINTEA VI (Barros, Guimarães, Lima, 2012). In this chapter, they decided to work in collaboration with a young researcher from Germany (Nathalie Touma) to provide an interpretation of government representations on the state of the art of ALE in Germany, Portugal and Sweden, focusing on certain categories of analysis that are set out below and which include the above-mentioned publications.

\section{Theoretical and methodological considerations}

Three ALE social policy analytical models will be briefly described, referring readers who wish to look at this proposal in more detail to the book by Lima and Guimarães (2011): 
the democratic-emancipatory model, in which democratic participation and critical education are very important in relation to ALE actions, in particular popular and community education; the modernisation and state control model, based on public provision, the intervention of the welfare state and generally dominated by second-opportunity education guidance; and the human resources management model, in search of economic modernisation and the production of skilled labour, led by vocationalist ideologies for the production of human capital.

These are models that, thanks to their breadth, seek to understand the very different public policies adopted in countries and regions that are themselves also very different.

Despite the identification of three distinct ALE public policy models, independent of each other, it is important to note that their construction is part of a continuum or imaginary theoretical line where each model occupies a specific position. This means that the three models, although different from one another, are not exclusive and can even coexist. So cross-fertilisation or hybridisation is possible: rather than rigid and artificial possibilities of analysis, it is expected that these models can be regarded as heuristic devices for understanding public policies on ALE. The discussion on the developments in ALE based on policy documents and public policies implemented by various countries therefore shows that, in a particular period, one or two models had a higher profile than the others, or other. But the dominant character of any one model at a particular time, at the expense of the previous ones, does not mean that the subordinate models simply vanish from the scene, tending towards a marginal survival, sometimes offering active resistance and at others persisting in a restricted, muted or modest form. In fact, though many countries favour policies based on the human resources' management approach and on appeals to the market and civil society, other models are also used: some are linked to strong state intervention in the development of adult education and training systems or to engaging civil society in the promotion of various public provisions. Since there may be some crossovers in the models the reality can be marked by a considerable hybridism of policy decisions, which should be examined in light of the models proposed.

The public policy models on ALE are characterised through different categories of analysis, each of which comprises several intrinsically consistent dimensions. These analytical categories are: political-administrative guidelines, political priorities, organisational and administrative dimensions, main conceptual elements of public policies. 


\section{Political-administrative guidelines}

These orientations relate to the laws, rules and norms that allow a public policy to be adopted. They consist of the legislative apparatus that provides the means for a policy to be implemented and include the establishment of conditions for accessing ALE initiatives and the involvement of the people attending them, the financing, controlling and evaluation of the actions proposed, and the organisation and management related to the development of these activities.

\section{Political priorities}

The political priorities concern the ends assigned to ALE, and the domains that a public policy focuses on, the relevant objectives and targets, target-groups and the amount of public funds allocated.

\section{Organisational and administrative dimensions}

These relate to the organisation, administration and management involved in adopting a public policy, including centralised and decentralised structures, the procedures and technical processes involved in carrying out ALE activities, quality assurance processes, evaluation and accountability procedures.

\section{Conceptual elements}

These are concerned with the theoretical references underlying the ends, methods and processes inherent to implementing a public policy, for instance, ALE conceptions, pedagogical models, forms of participation and assessment, etc.

\section{The democratic-emancipatory model}

One of the most significant aspects of this model is the influence of critical pedagogies that uphold an idea of education as lifelong, humanist, aimed at social development, and promoting social responsibility, a collective destiny, and democratic and cosmopolitan citizenship (cf. Lima 2005). From this viewpoint, public policies are instruments of social, economic, political, and cultural action for the state. The state is thus a determining agent for planning and intervention (Griffin, 1999a, p. 334), although open to challenge with respect to bureaucratic state control and under pressure to undertake democratic and participatory reinvention, particularly through social movements. A multi-faceted view of development (social, economic, cultural, and political) and participation (social, political, and civic) is allied to this understanding. One of the political priorities of this model is to build a democratic 
and participatory society by means of a fundamental social right: education. Concerns with solidarity, social justice, and the common good are important and justify the establishment of basic education and education for democratic citizenship programmes, and the setting up of a broad range of initiatives to promote a civic sense and a critical and thoughtful capacity (cf. Guimarães, 2011).

With respect to the conceptual elements of this model, attention is drawn to the educational (not simply instructional) nature of the initiatives, through which local cultural traditions are valued, along with the adults' own life experience and understanding of the world. Based on ethical and political principles, often associated with participatory action-research in coordination with programmes backed by social policies (for childhood, the third age, vocational training, or for fighting poverty, including local job promotion, rural development initiatives, etc.), these actions' chief goal is to promote critical-based education, aimed at the transformation of decision-making power, and at social change.

There is a concern here to connect the individual facet of the act of learning to the collective facet of what is learned. The goals of learning are above all of a social and indirectly academic nature. Learning starts in social relations, continues throughout life, in all its aspects, based on social needs and leading to educational programmes that are meant for adults and their perceived needs. Here, the education and learning contexts are expanding to other areas (apart from school) in life, and there is a flexibility of times and spaces in which to learn, as there is in content and methods (cf. Sanz Fernández, 2008, p. 82).

In terms of the political-administrative guidelines, the actions implemented under the democratic-emancipatory model are noted for the decentralised control of education policy and administration and for the high degree of autonomy enjoyed by the organisations that stimulate ALE actions, including those linked to civil society and social movements.

This critical education model has had a major impact in different contexts of ALE. Until the mid- $20^{\text {th }}$ century in Europe, workers' groups and trade unions, folk high schools, social movements, pedagogical missions, and so forth sought to build a "project to promote political and civic awareness in citizens" (Finger \& Asún, 2001, p. 97). Influenced by the ideas of the Enlightenment or by others that are about workers' and trade union education, many of these projects were designed to solve the problems faced by societies and benefited from charitable and voluntary work.

For example, in Sweden, a number of bodies were created after 1868 to implement actions to promote education (folkbildning). These organisations were notable for their freedom, independence of thought and autonomy and they developed 
group activities, open classes, and other initiatives that aimed to meet specific educational needs. At first these popular education initiatives were attended by landowners, and later the workers used them as a way of gaining power (cf. Norbeck, 1979; Vallgårda \& Lima, 1985; Larsson, 1998, 2001).

Among the popular education actions undertaken in Sweden and other Scandinavian countries, study circles have turned out to be particularly significant initiatives in terms of fostering democracy, self-management and critical and transforming education (cf. Vallgårda \& Norbeck, 1986; Larsson, 1998, 2001).

In Germany, the Society for the Propagation of Popular Education, founded in 1871, was set up to support the development of popular emancipation movements. This body worked to set up other organisations that would spread culture and knowledge, establish public libraries and increase the number of classes and presentation sessions open to the public. University outreach was also invigorated and here the aim was to disseminate academic knowledge in accordance with the principles of the Enlightenment (cf. Nuissl \& Pehl, 2000, p. 11; Lattke, 2008, p. 41). This Society's efforts, and those of others in the field of popular education, led to that very expression, popular education, becoming widespread. Popular education started out as education of ordinary people who were distinguished from those who had an erudite culture. It was an elementary, entry-level, education that expressed boundary between the various social groups and between other bodies that stimulated job-related training actions and received public funds in return (cf. Nuissl \& Pehl, 2000,p. 12; Lattke, 2008, p. 41). This was how civil society gained strength, becoming self-organised and demanding, with respect to both the state and the market.

Portugal developed later and it was not until, initially, in the First Republic (1910-1926) and then after the democratic revolution in 1974, that democratic and emancipatory initiatives were developed with government support. These actions were fostered by state bodies, but to an even greater extent by non-state ones, in all kinds of projects and programmes. The popular education activities that were developed in the wake of the 1974 revolution (April $25^{\text {th }}$ ) elucidated this aspect, in particular the work done between popular associations and the Ministry of Education through the General Directorate of Permanent Education. Several quite separate initiatives were implemented, in particular the literacy programme, cultural and socio-educational projects, basic education actions, etc. In this complicated historical context there was an explosion of highly varied initiatives, actions included in community development projects undertaken by popular associations, by relatively informal groups that were motivated to respond to requests that emerged in local communities. 


\section{The modernisation and state control model}

This model values education in a context of social and economic modernisation. In light of the interplay between democracy, economics, society, and culture, education policies seek to unite functions that favour the processes of accumulation and legitimation, emphasising the interventionist, dirigiste character of state action. With a backdrop of a Fordist work pattern, the state controls the means and ends of public policies, for which it profits from a mandate to achieve certain goals and outcomes that target social justice, equality, family and community solidarity, and social cohesion. As education is an essential pillar of social policies in the construction of a democratic capitalist state, it involves a set of processes that are directed at ensuring equal opportunities for everyone, especially for those who are less able to get education and training. The rules associated with increasing and expanding opportunities of access to successful education are getting more and more attention from the government. Its impact is therefore increasingly evident in practice, leading to the formalisation and bureaucratisation of processes (cf. Lima, 2005). This model stresses the functional nature of education, in which the welfare state fosters economic growth and full employment. Education, seen above all as the teaching given in school, is essential to training citizens (cf. Griffin, 1999a).

The most striking conceptual elements are related to reducing the field of adult education to formal and second chance education and to stressing the importance of targeting vocational training at promoting economic growth. This is why the conception of ALE in this model is largely reduced to the tasks of "reading, writing, and arithmetic", to learning of an academic, educational nature and to schooltype vocational training. Memorising is emphasised and read texts are the main source of dialogue with the reader. Sanz Fernández says that it therefore promotes "receiving and mastering literacy". Seeking to "discipline the adult population" and to "educate to obey", it advances the instrumental (not social) use of reading and writing, and the results of education practices illustrate the efforts at social control and the reproduction of social inequalities (Sanz Fernández, 2008, p. 75 ff.).

In the European countries that share the welfare state format adult education took a form that is reminiscent of the centrality of the state in the context of specific historic circumstances (cf. Guimarães, 2011). These circumstances led to some countries putting in place mechanisms for formal education (for example, instruction and compensatory education) and non-formal education (retraining and professional adaptation, promotion of social participation, etc.) that were more structured than those seen up to the $2^{\text {nd }}$ World War.

But there were variations. These are evident in the political ends which aimed to integrate workers as citizens into the modern state; they were intended to meet 
the expectations of the people (and their children); and they guaranteed the public funding of education and training (cf. Esping-Andersen, 1990; Mishra, 1995; Giddens, 1999; Law, 1998; and others).

In post-war Germany, for example, adult education was directed toward new goals related to re-education for democracy, through political education (Politische Bildung) promoted by community education centres, by the education centres in the Länder, and by foundations. Companies, faith-based organisations and trade unions kept up the impetus for educational formats that already prevailed (cf. Nuissl \& Pehl, 2000, p. 13). The schools, meanwhile, proposed a varied range of evening courses, lectures, courses on literature, religion, history, politics and music, the teaching of German and foreign languages, improving health, and so forth. They were voluntary activities and often involved people who already had some knowledge of the topics covered. On the whole these bodies did not offer courses that led to a diploma. Despite the range of programmes not many workers took advantage of them. It was different for boarding schools, since the content varied in terms of the trade union, religious, economic or social tendencies favoured by whoever ran them. Diversity also characterised the adults who took part in these initiatives; it was argued that these boarding schools helped to forge a high degree of social cohesion since they brought together people from different social groups (cf. Raapke, 2001, p. 188).

ALE played an important part in promoting the ideas of the Enlightenment until the 1960s and, as since then it integrated education policies, the responsibility of the state was obvious. It seemed that actions run by civil society bodies in the same decade had these goals diverted, since in an increasingly more plural context the organisations were more reliant on their ideological positions (religious and trade union related, for example) (cf. Nuissl \& Pehl, 2000, p. 14).

But it was felt that the state should be responsible for stimulating a fourth sector in the education system, one that was stable and solid. This new sector included areas like continuing vocational training, political education and liberal education for adults (cf. Lattke, 2008). In 1970 the state, through the national education council, sought to incorporate different facets of the education system. It aimed to structure and organise centrifugal tendencies that were apparent in education, especially in adult education. That was when another expression emerged, continuing education (Weiterbildung), to describe the rebuilding of adult education; this expression came to include continuing vocational education, vocational retraining and compensatory adult education of a non-formal nature (cf. Raapke, 2001, p. $188 \mathrm{ff}$.). The older expression for ALE (Erwachsenenbildung) kept its association with liberal, general, civic and political education (cf. Lattke, 2008). 
In Sweden, after World War II, popular education (folkbildning) emerged as the fundamental domain for promoting social change. In this it was a progressive force, a reformist project in development, since "the study circles have been educational arrangements which have chosen contents, forms and participants so as to promote social change" (Larsson, 1998, p. 58). But the dialectics established between popular education and Swedish society became less obvious after World War II. For example, since then the state has been supporting folk high schools and paid the monitors of the study circles, the teachers and the administrative staff. It has also given scholarships to students. It should be noted that these institutions nonetheless enjoyed a high degree of autonomy; they could set goals, decide on the nature of the education (usually comprehensive), teaching methods (usually active) and the participants, who came from various social groups (though these mostly belonged to the working middle class), and the length of most of the courses (short, medium or long duration) (cf. Vallgårda \& Lima, 1985).

Meanwhile, with consolidation of the welfare state, the minimisation of social problems and increasing income earned for work led to the emergence of active social policies as a determining factor for economic stability and the promotion of full employment. As a result, training programmes aimed at integrating people into the labour market were implemented and so, as Rubenson says, the reform of adult education demonstrated the influence of the theory of human capital (cf. Rubenson, 2004). In the same vein, the successive reforms in the second half of the $20^{\text {th }}$ century allowed the formal education system to expand to include more and more people. Recurrent education appeared as a basic idea used to argue that everyone should enjoy equal rights with respect to education, regardless of their social origin, gender, etc. (cf. Rubenson, 1994).

In Portugal this rationale became clearer after the Basic Law for the Education System and Portugal's membership of the European Economic Community (EEC). In terms of priorities, therefore, we should note the return to educational guidance and second-chance education, i.e. compensatory education. This return was confirmed by the emphasis given to second-chance education in evening classes. Supplementing the endeavour to modernise the economy, this rationale downgraded issues of literacy, basic education and popular education. These were areas of intervention seen, as far as public policies were concerned, as being generically incompatible with the idealised place and coveted status of an EU country whose main challenges were identified with its economic modernisation and in relation to infrastructure, with the efficacy and efficiency of public and private management, increasing productivity, and internationalisation and competitiveness in the economy (cf. Lima, 2005). 


\section{The human resources management model}

This model stresses the withdrawal of the state that is justified by the internationalisation of the economy, global competition, and diminishing public resources (cf. Guimarães, 2011). Despite the problems arising from an adverse economic, social, and political context, public policies favour the maintenance of redistributive principles, given that lifelong learning remains a way of providing education and training (a function of the state) and that it embraces the concern of preserving the state's strategic ability to establish policy, albeit on an increasingly short or medium-term basis. But the state is also losing control of the purposes of education. The reduction of its ability to determine the results of these policies has become clearer, despite the efforts to regulate and the adoption of measures of enforcement (cf. Griffin, 1999a, 1999b).

Although education retains an important collective dimension, the individual acquires new responsibilities. Among these are "learning to adapt oneself" to the changes being faced, and "being able to choose and decide" about the best options for the social and economic transformations taking place. This is where we find education and economics drawing closer, in an appeal for greater productivity, competitiveness, and flexibility; and it is in this context that we find an understanding of education (training and learning) as an investment, with frequent analogies between training and financial capital. In these policies, learners are those who "learn throughout life" in places and at times outside the school context, and those who are "better educated", that is, those who have spent more time at school, and are "better trained" in terms of knowledge and skills related to the workplace. Some degree of interaction between the school and the lifelong learning strategies outside this organisation is thus sought. Although they have different emphases, these policies are backing the maintenance of state involvement, while they denote a distance from training policy and planning and a nearness to "government strategies" (Griffin, 1999a, p. 339).

The human resources management model focuses on the acquisition of competences (which are not promoted in the provisions currently available in the education systems). The term competence may embrace a wide variety of meanings; here, it is taken to be something that adults should have, because it is believed that each individual must have the "competence needed to compete", namely to gain employment (cf. Lima, 2005). Despite its relevance, competence has been viewed as knowledge acquired by each individual from his/her experience in different non-formal and informal contexts. Above all, it has a utility value. It shows that individuals are able to carry out a specific task. In addition, competence has been seen as measurable ability and knowledge that has yet to be assessed and formally 
documented. Consequently, learning is to convert one-self "into one of the most attractive investments for businessmen and one of the priority claims (besides pay and health) of workers". In this scenario, "the productivity and competitiveness of economic agents are based on their ability to process and apply knowledge effectively" (Sanz Fernández, 2008, p. 94).

In Germany the possibility of establishing a permanent training market was discussed in 1984. It would be linked to giving adults qualifications with the aim of combating unemployment. Although it was not fully followed, according to Nuissl and Pehl, this discussion marked the start of the steady withdrawal of the state from ALE by instituting competition between promoters of adult education, at federal level and within the states (Länder). But even today the Länder retain certain control and regulatory functions, typical of the welfare state (cf. Nuissl \& Pehl, 2000).

Since then, according to Raapke (cf. 2001), though deregulation has not been complete, there have been important reductions in the financial, material and human resources bestowed on adult education. These reductions had an unequal distribution: in some places ALE seemed to strengthen its position since some public organisations still had some budgetary independence, but market mechanisms appeared to rule in others. But the overall responsibility of the state declined and it now has fewer responsibilities for adult education; in fact it was often argued that adults should take charge of their own education and training and that state support could only be justified in very special circumstances or for particular social groups. So training for the common interest involved some tension, since the state and local authorities still controlled and funded some initiatives, though this represented only a small part of continuing education (Weiterbildung).

In Portugal the policies adopted from the end of the 1990s, like adult education and training, which can be related to this model, tended toward modernisation "so as to respond positively to the so-called challenges of European integration, requiring the state and public administration to make a greater structural effort and devise active policies for integration and convergence". These concerns were not completely unknown in Portugal since, even in the 1950s, the significance of modernisation and the content of measures dependent on efforts to develop the economy were discussed. But after Portugal joined the EEC and adopted policies influenced by guidance issued by this supranational body, the emphasis was on ideas like "useful learning", "acquisition of skills to compete", "lifelong upskilling" and "education for employability". It was asked to adopt measures that were "instant and short term that chose 'trainability' over education, and individual 
responsibility over social responsibility and collective destiny, as pillars of the proposed policies" (cf. Lima, 2005, p. 46).

The recognition of learning acquired throughout life became a central issue in policy discourses in recent times in Sweden. This involved several risks. With respect to the Northern European models of the welfare state and adult education, in the last twenty years universalist and focused on employment, they have faced two threats, according to Rubenson. The first concerned political discourses in which education was strengthened as long as it considered the needs of the market and individual responsibility in adapting to the challenges that the knowledge economy entailed. In these discourses the needs of individuals, especially those arising "from the needs of the labour market", were the starting point for planning the provision of education. The second threat was linked to lifelong learning as public policy and individual project. In this context the collective efforts of the social movements and the associations that were promoting the study circles, for example, were downplayed and the traditional connection between civil society and popular education came out weaker (cf. Rubenson, 2004, p. 44).

This reasoning is based on the idea popular in political discourses that Swedish society, like other countries, is at risk and so the skills of its people are important to the construction of a knowledge economy. Everyone should have the competences that make them employable, and in this context the recognition, accreditation and validation of competences are essential. The skills that people develop during the course of their life should be utilised. In this regard, Andersson and Fejes state that the validation of competences was introduced into the discourse and public policies in Sweden in 1996, thereby increasing the chance of gaining qualifications. It also allowed education and training to develop to be more useful and relevant to people, since "there was no need to learn what was learned in the past". Competence took on a new meaning, stressing its usefulness (cf. Andersson \& Fejes, 2005).

\section{Analytical categories and dimensions}

The three analytical models briefly presented here simultaneously comprise heuristic dimensions of research and didactic dimensions. They should be viewed as proposals open to social research and to the historical, cultural and educational diversity of the different contexts under study. This means that there may be a need to increase the number of models or to build sub-models and specifications within some or all models now presented. They are not the realities and political specificities of ALE that are expected to integrate perfectly into the 
three analytical models proposed, instead they are the analytical models that should prove sufficiently open and flexible to handle the multiplicity of social policies of ALE.

A greater degree of openness is required in the case of aspects which are indicated below for each of the four categories of analysis presented earlier (Table 1). The inventory offered by the authors is merely indicative, in terms of both theoretical consistency and empirical occurrences in various contexts that have been studied over the last decade. Just as policy documents such as the national reports submitted to CONFINTEA VI are often marked by a certain "rhetoric" (Keogh, 2009 , p. 9), by normative and mobilisation aspects that are typical of the role historically played by UNESCO (Milana, 2014), by dominant approaches and concepts of fashion, so, even in the case of our interpretation of instruments, it is necessary to avoid the nominalist approaches that reduce complexity, contradictions and paradoxes present in political speeches to the search for certain words or concepts. It is not, for instance, because legislation or a government report repeatedly mentions the words democracy and participation that they can immediately be integrated in the democratic-emancipatory model. There are, of course, several concepts and very distinct practices of democracy and participation, so it is necessary to understand the political-educational rationale and the historical and cultural context in which these concepts should be interpreted. In practical terms, it is more plausible to find practical situations that are characterised by the need to muster different analytical models simultaneously rather than a single pure and internally consistent mode. 
Table 1: Analytical policy models of ALE (Adapted from Lima \& Guimarães, 2011)

\begin{tabular}{|c|c|c|c|}
\hline $\begin{array}{c}\text { Rationales predo- } \\
\text { minating in adult } \\
\text { learning and edu- } \\
\text { cation policies } \\
\text { (Social Policies } \\
\text { Models) } \\
\text { Categories } \\
\end{array}$ & $\begin{array}{c}\text { Democratic-Eman- } \\
\text { cipatory Model } \\
\text { (Dimensions of } \\
\text { DEM) }\end{array}$ & $\begin{array}{l}\text { Modernisation and } \\
\text { State Control Model } \\
\text { (Dimensions of } \\
\text { MSCM) }\end{array}$ & $\begin{array}{l}\text { Human Resources } \\
\text { Management Model } \\
\text { (Dimensions of } \\
\text { HRMM) }\end{array}$ \\
\hline $\begin{array}{l}\text { Political-adminis- } \\
\text { trative guidelines }\end{array}$ & $\begin{array}{l}\text { * Polycentric educa- } \\
\text { tion systems based } \\
\text { on participatory } \\
\text { democracy } \\
\text { * Decentralised } \\
\text { control of policy and } \\
\text { administration of } \\
\text { education } \\
\text { × Appreciation of } \\
\text { bottom-up dyna- } \\
\text { mics } \\
\text { * Support of local, } \\
\text { self-managed initi- } \\
\text { atives } \\
\text { ^ Leading role of } \\
\text { education associ- } \\
\text { ations and social } \\
\text { movements } \\
{[\ldots]}\end{array}$ & $\begin{array}{l}\text { * Appreciation of edu- } \\
\text { cation in the effort to } \\
\text { modernise, encoura- } \\
\text { ging efficacy, efficiency } \\
\text { of public and private } \\
\text { management, increa- } \\
\text { sing productivity, the } \\
\text { internationalisation } \\
\text { of the economy and } \\
\text { competitiveness in } \\
\text { capitalist democracies } \\
\text { * Centralised control } \\
\text { of policy and adminis- } \\
\text { tration of education by } \\
\text { the state (supply-side) } \\
\text { * Appreciation of } \\
\text { state intervention as } \\
\text { guarantee of universal, } \\
\text { free public education } \\
{[\ldots]}\end{array}$ & $\begin{array}{l}{ }^{*} \text { Leading role ascribed } \\
\text { to the market, civil so- } \\
\text { ciety and the individual } \\
\text { (demand-side) } \\
{ }^{\star} \text { Adoption of active } \\
\text { policies for integration } \\
\text { and convergence in EU } \\
\text { context } \\
{ }^{\star} \text { Combination of } \\
\text { logic of public service } \\
\text { and programme logic, } \\
\text { although the program- } \\
\text { me logic in EU backed } \\
\text { projects dominates } \\
{ }_{\star} \text { Promotion of part- } \\
\text { nerships between state } \\
\text { and other institutional } \\
\text { actors } \\
{[\ldots]}\end{array}$ \\
\hline
\end{tabular}




\begin{tabular}{|c|c|c|c|}
\hline $\begin{array}{c}\text { Rationales predo- } \\
\text { minating in adult } \\
\text { learning and edu- } \\
\text { cation policies } \\
\text { (Social Policies } \\
\text { Models) } \\
\text { Categories }\end{array}$ & $\begin{array}{c}\text { Democratic-Eman- } \\
\text { cipatory Model } \\
\text { (Dimensions of } \\
\text { DEM) }\end{array}$ & $\begin{array}{l}\text { Modernisation and } \\
\text { State Control Model } \\
\text { (Dimensions of } \\
\text { MSCM) }\end{array}$ & $\begin{array}{l}\text { Human Resources } \\
\text { Management Model } \\
\text { (Dimensions of } \\
\text { HRMM) }\end{array}$ \\
\hline Political priorities & $\begin{array}{l}\text { * Construction of a } \\
\text { democratic and par- } \\
\text { ticipatory society } \\
\text { * Integration of } \\
\text { basic, non-govern- } \\
\text { mental groups in } \\
\text { the definition and } \\
\text { adoption of public } \\
\text { policies } \\
\text { × Solidarity, social } \\
\text { justice, common } \\
\text { good } \\
\text { × Education establis- } \\
\text { hed as a basic social } \\
\text { right } \\
\text { × Political, economic } \\
\text { and cultural change } \\
\text { ^ Education and } \\
\text { training as process } \\
\text { of empowerment } \\
\text { [...] }\end{array}$ & 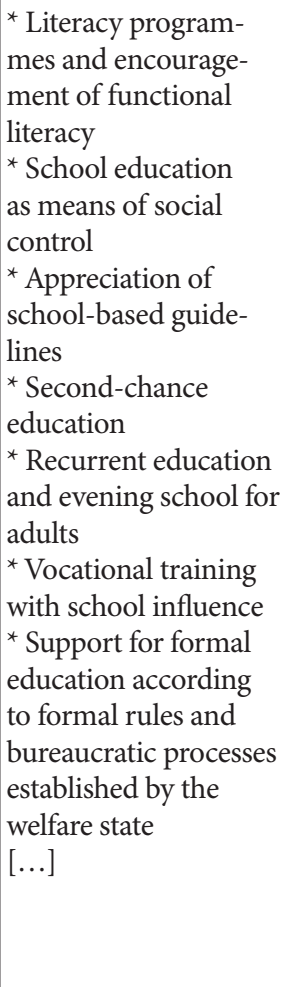 & 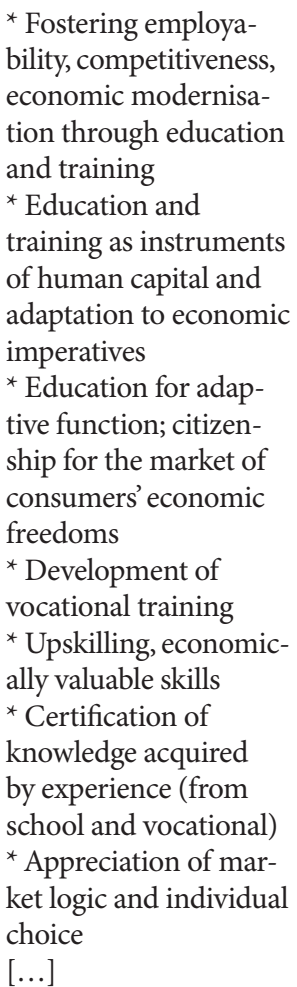 \\
\hline
\end{tabular}




\begin{tabular}{|c|c|c|c|}
\hline $\begin{array}{l}\text { Rationales predo- } \\
\text { minating in adult } \\
\text { learning and edu- } \\
\text { cation policies } \\
\text { (Social Policies } \\
\text { Models) } \\
\text { Categories }\end{array}$ & $\begin{array}{c}\text { Democratic-Eman- } \\
\text { cipatory Model } \\
\text { (Dimensions of } \\
\text { DEM) }\end{array}$ & $\begin{array}{l}\text { Modernisation and } \\
\text { State Control Model } \\
\text { (Dimensions of } \\
\text { MSCM) }\end{array}$ & $\begin{array}{l}\text { Human Resources } \\
\text { Management Model } \\
\text { (Dimensions of } \\
\text { HRMM) }\end{array}$ \\
\hline $\begin{array}{l}\text { Organisational } \\
\text { and administrati- } \\
\text { ve dimensions }\end{array}$ & $\begin{array}{l}\text { * Appreciation of } \\
\text { intervention of civil } \\
\text { society (associations } \\
\text { and community sec- } \\
\text { tor concerned with } \\
\text { adult education, po- } \\
\text { pular associations) } \\
\text { ^ Local self-organi- } \\
\text { sation, autonomy } \\
\text { and creativity of } \\
\text { bodies behind } \\
\text { initiatives } \\
\text { ^ Participatory } \\
\text { forms aiming at } \\
\text { collective decisions, } \\
\text { i.e. participatory } \\
\text { budget } \\
\text { [...] }\end{array}$ & $\begin{array}{l}\text { * School as central } \\
\text { organisation in } \\
\text { public adult education } \\
\text { policies } \\
{ }^{\star} \text { Courses for young } \\
\text { people and adults } \\
\text { ^Strongly educational } \\
\text { administrative and } \\
\text { management proce- } \\
\text { dures } \\
{[\ldots]}\end{array}$ & $\begin{array}{l}\text { * Adoption of mana- } \\
\text { gerialist, procedures } \\
\text { for induction and } \\
\text { management of human } \\
\text { resources } \\
\text { * Appeal to non-state } \\
\text { organisation (third } \\
\text { sector and market) } \\
\text { involvement } \\
\text { * Partnerships } \\
\text { × Creation of state } \\
\text { management and } \\
\text { administration struc- } \\
\text { tures having some } \\
\text { independence, though } \\
\text { with limited scope for } \\
\text { educational interventi- } \\
\text { on (minimalist struc- } \\
\text { tures, for induction, } \\
\text { mediation) } \\
{[\text {...] }}\end{array}$ \\
\hline
\end{tabular}




\begin{tabular}{|c|c|c|c|}
\hline $\begin{array}{c}\text { Rationales predo- } \\
\text { minating in adult } \\
\text { learning and edu- } \\
\text { cation policies } \\
\text { (Social Policies } \\
\text { Models) } \\
\text { Categories }\end{array}$ & $\begin{array}{c}\text { Democratic-Eman- } \\
\text { cipatory Model } \\
\text { (Dimensions of } \\
\text { DEM) }\end{array}$ & $\begin{array}{l}\text { Modernisation and } \\
\text { State Control Model } \\
\text { (Dimensions of } \\
\text { MSCM) }\end{array}$ & $\begin{array}{l}\text { Human Resources } \\
\text { Management Model } \\
\text { (Dimensions of } \\
\text { HRMM) }\end{array}$ \\
\hline $\begin{array}{l}\text { Conceptual } \\
\text { elements of public } \\
\text { policies }\end{array}$ & $\begin{array}{l}\star \text { Adult education } \\
\text { as a sector charac- } \\
\text { terised by hetero- } \\
\text { geneity and diversity } \\
{ }^{*} \text { Appreciation of } \\
\text { basic education, } \\
\text { popular educa- } \\
\text { tion, basic literacy, } \\
\text { socio-cultural and } \\
\text { socio-educational } \\
\text { animation } \\
\text { ^ Educational nature } \\
\text { of the actions, } \\
\text { appreciation of } \\
\text { collective knowledge } \\
\text { and experience } \\
{ }^{\star} \text { Ethical and poli- } \\
\text { tical dimension of } \\
\text { education } \\
\star \text { Participatory } \\
\text { action-research pro- } \\
\text { jects, participatory } \\
\text { research } \\
\star \text { Basic civic educa- } \\
\text { tion (aims at poli- } \\
\text { tical and economic } \\
\text { democratisation, } \\
\text { power relations } \\
\text { transformation, } \\
\text { social change, em- } \\
\text { powerment) } \\
\text { [...] }\end{array}$ & $\begin{array}{l}\text { * Formal education of } \\
\text { adults as a social right } \\
\text { * Integration of non- } \\
\text { formal education into } \\
\text { the public education } \\
\text { system according to } \\
\text { the latter's rules } \\
\text { * Education as instru- } \\
\text { ment for promoting } \\
\text { equal opportunities } \\
\text { ^ Appreciation of } \\
\text { vocational training } \\
\text { (according to educa- } \\
\text { tional guidelines) } \\
\text { ^ Adult education as } \\
\text { second-chance edu- } \\
\text { cation and recurrent } \\
\text { education } \\
{ }^{\star} \text { Education for mo- } \\
\text { dernisation and eco- } \\
\text { nomic development of } \\
\text { the nation state } \\
\text { [...] }\end{array}$ & 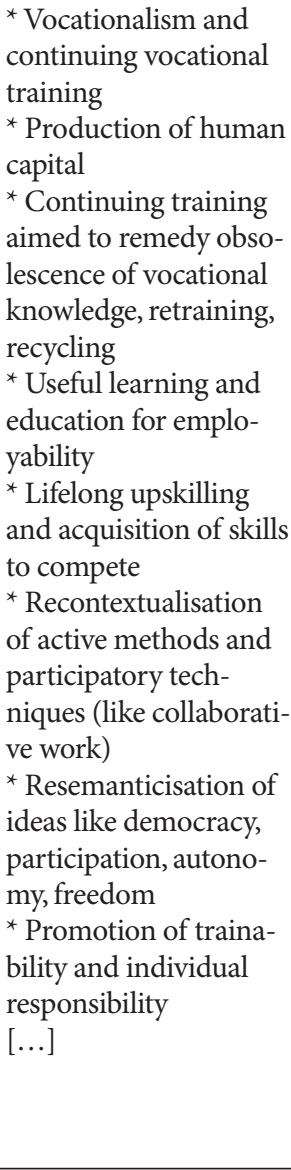 \\
\hline
\end{tabular}




\section{National reports as policy documents and representations of ALE}

National reports submitted to CONFINTEA VI are ALE policy documents that are particularly useful for drafting a preliminary analysis based on the three analytical models proposed by Lima and Guimarães (2011). Indeed, these documents represent rational choices made by government authorities in each of the participating countries as to what in that historic moment they understood to be the organisation, priorities and the development of ALE. They are, therefore, government representations of social policies of ALE that have been adopted internationally, involving historical and cultural aspects, and perhaps some diversity of policy guidelines. In each national report we can find normative statements and implicit and explicit definitions of ALE as a field of policy and practices. The limitations of these documents are, moreover, those which depend on the greater or smaller distance between policy statements and the dominant social representations on the one hand, and effective and practical achievements in terms of specific activities and projects of ALE, on the other.

\section{Political-administrative guidelines}

As mentioned before, Germany has a tradition in the field of public policies on ALE (Nuissl \& Pehl, 2004), as stated in the report under consideration. In line with this expression and with that tradition, this domain refers to processes that happen after primary education and carry on throughout life but not including higher education. Over the past four decades, public policies for this sector have been framed by the Deutscher Bildungsrat of 1970, which states that ALE is the "the necessary and lifelong complement to initial education (...), the continuation or the recommencement of organised learning following completion of the training phase of whatever length" (Germany, 2008).

This broad definition of ALE could fit a wide range of policies. The role assigned to the state of defining values and principles of action plays a part in this finding, particularly when the report in question states that

"The activity of the state in the area of continuing education is generally limited to the stipulation of principles and basic parameters and to the introduction of rules to ensure that continuing education is properly organised and supported" (Germany 2008, p. 147).

It goes on to say that "Continuing education is less regulated by the state than other areas of education. The field of continuing education features a high level of pluralism and competition among providers" (Germany, 2008, p. 147). This raises the possibility that aspects of a range of ALE policies are likely to be found. 
This likelihood is reinforced in the document under review since it mentions the intervention of other local actors such as non-governmental and non-profit organisations that could be closer to democratic and emancipatory policies and critical adult education practices of a participatory and transforming nature. But the German report emphasises the implementation of activities by state and nonstate organisations related to work and employment, both commercial and nonprofit. Therefore, although it can be said that in terms of principles and values the possibility is mentioned that the principles of three different models of public policy could be adopted, stress is nonetheless placed on aspects consistent with the models of modernisation and state control and of human resources management.

The range of entities involved in the public provision of ALE and the implementation of very varied provision indicates the importance accorded to the intervention of the Länder. The Länder have expertise in setting priorities and specific targets, taking into account the local dimensions in educational provision. This is why instances arise that can play a significant role in establishing and controlling the public provision (Germany, 2008, p. 156), in monitoring and evaluating the educational provision and in setting up local networks (Germany, 2008, p. 152). Because of the contextualised nature of the intervention of the Länder, possibilities of alternative intervention with respect to the state may arise. However, due to the centrality ascribed to the economic development in public policy on ALE in this country, there seems to be a strong relationship between the state and entities related to vocational training, private, for-profit and sectoral, which can be seen, for example, in the level of funding allocated to this sector (Germany, 2008, pp. 161-173). This option seems to favour the adoption of public policies to modernise and control, coordinated with other human resources management policies that cater to concerns about economic growth and increased productivity.

The Portuguese report differs from the other two because it takes adult education to mean "adult education and training". In keeping with this expression, this document only gives importance to basic education, i.e. to school certification, and to vocational training by obtaining the professional qualification and there is no mention of other sectors such as local development, which has a long history in this country, popular education, socio-cultural activities and so on. This preference for a more restricted expression for ALE certainly comes from a lack of tradition in public policy, as well as the intermittent and discontinuous nature of many of the programmes implemented in Portugal in the last five decades (Lima, 2005).

In implementing ALE public policy, the state seems to be a key player in the context of just one action programme, the New Opportunities Initiative. Accordingly, the focus is on central government bodies in the formulation and 
adoption of this policy strategy. While the two other reports talk about different levels of intervention, central and local, the Portuguese paper highlights the role of public state bodies at central level, with no mention of other agencies, state or non-state, in the definition of public provision.

It says, however, that to achieve the goals of ALE public policy, other state and non-state entities, commercial and non-profit, are involved, but does not address the role of these organisations in other areas of ALE, nor is any kind of autonomy foreseen in the design, development or evaluation of provision included in the New Initiatives Opportunities. Moreover, it is envisaged that local-level entities should develop public provision, although the report in question does not make it clear what tradition these entities have in ALE, or what interaction can be achieved between a pre-defined intervention programme that has strict operating rules and these entities, with their knowledge of the localities in which they operate. It thus seems to note an instrumentalisation of various entities regarding political purposes chosen based on problems that seem to have a national meaning, such as the Portuguese "educational backwardness" and the lack of competitiveness of the national economy, without any consideration of the needs, expectations and motivations of local promoters and individuals.

As for the Swedish report, this has been drafted in a country with a long tradition in ALE public policy, particularly in the context of popular and non-formal education (Larsson, 1998). Regarding state action, there is a commitment to coordination between principles and priorities, actors and different levels of intervention. The report under consideration stresses the role of the state in setting policy priorities and intervention strategies. In this regard, it says that,

"The role of the state is to create the opportunities for versatile learning and the national strategy to support both organised and non-organised learning situations" (Sweden, 2008, p. 4).

While the state has the task of establishing the principles, values and guidance of public policies, it is at local level that the public provision is developed, specifically the setting of goals and the educational outcomes to attain. Thus, ALE in this country is decentralised (Sweden, 2008, p. 3), as it is locally, in the municipalities that public provision is organised and implemented.

Like the German and Portuguese reports, this document also states that the purpose of the educational policies is to make Sweden a nation with a lifelong learning system of high quality, directed at economic growth and in line with the model of public policy for modernisation and social control. But, unlike the two other reports, there is a strong emphasis on ALE, which this document identifies as "adult education" on promoting social justice, democracy and citizen participation 
(Sweden, 2008, p. 4). Thus, it stresses interaction between the collective and individual dimensions of education, between promoting economic development and enhancing democracy, and between achieving equal opportunities and meeting the interests and educational needs of citizens. While the state retains the tasks of establishing priorities and developing public provision, through, for example, the allocation of funds (Sweden, 2008, pp. 13-15), this report contains a clear focus on the individuals, their interests and motivations, and their social and personal development. In this context, the intervention of local ALE entities has proved to be essential. There seems to be a commitment to interaction between the state, which provides conditions for the development of ALE policies, and local authorities, very varied, whether state or non-state, and the individuals in developing relevant learning that is useful to them (Sweden, 2008, p. 5), under the democratic and emancipatory guidelines and in light of other modernisation and social control guidance.

\section{Political priorities}

Participation in ALE arises in the three reports in question as a key political priority. This priority follows the trend of increasing adult participation in ALE actions recorded in many other countries (Bélanger \& Federighi, 2001) particularly noticeable from the 1990s. In line with this trend, the reports in question underscore the importance of maintaining and increasing levels of participation, though in different ways.

In the German report, the main priorities identified suggest there are public policies that seek to create a comprehensive system of lifelong learning, which can refer to a combination of models, with the spotlight on democratic and emancipatory policies. In this regard, it says that adult education aims "to enable [people] to develop their personal, professional and social prospects free from the daily pressures of work in a way that extends beyond merely updating their skills for the workplace" (Germany, 2008, p. 171).

This document highlights the need to encourage all citizens to take part in ALE, by accomplishing equality of opportunities and respect for the voluntary nature of participation by adults. It also looks closely at strategies for the social inclusion of certain social groups, such as the elderly, the 50-plus initiative (2007), and immigrants, with reference to the 2005 Immigration Act and the National Integration Plan, 2006. It also includes the development of provision in areas as diverse as combating poverty, basic education, vocational training, environmental education, for example, in the context of UN Decades and political and civic education (Germany, 2008, pp. 158-160). 
Many of these initiatives are intended to strengthen inclusion and social cohesion and share the educational goals specified by the state, in order to build an integrated lifelong learning/training/education policy. Note however that this report also emphasises that increased participation in ALE should consider economic development, particularly when it states that "Continuing education and lifelong learning are key prerequisites for the strengthening of innovative potential in Germany" (Germany, 2008, p. 160). This emphasis falls on the priorities of modernisation and social control and human resource management. At the same time, the focus of various programmes on the elderly and immigrants is based on a desire to make the German economy competitive within Europe and worldwide, and there is a perceptible stress on the role of ALE in increasing productivity and flexibility of the individuals in the labour market. These concerns clearly approach the human resources management approach.

The Portuguese report mentions the aim of increasing participation rates in ALE by increasing the levels of basic education and vocational qualification certification of the Portuguese population in an effort to accomplish modernisation and social control policy guidance. That purpose is stated in a single programme: the New Opportunities Initiative. This purpose is supplemented with another that envisages ALE public policy interacting with economic development strategies such as the National Employment Plan and the Technological Plan (Portugal, 2008 , p. 2), in which case the concern with the principles of modernisation and social control and human resource management is evident.

These purposes arise in the context of globalisation and the restructuring of the Portuguese economy, also in keeping with the lifelong learning perspective established by the EU as part of human resources management principles, and with values related to social cohesion aimed at the integration of different participants in ALE, in line with the modernisation and social control and democratic and emancipatory models.

Concerns about participation are important in the Portuguese report, although there are no explicit references to particular social groups that may be in disadvantaged situations in educational terms. While this is an interesting justification, it is still strange to choose a single priority, that of including a significant number of adults in two ALE certifying and/or qualifying provisions in a short time, given that the established time frame runs from 2000, when the indicated provisions were created and 2010, the end of the New Opportunities Initiative. We can thus see the temporary nature of a programme that calls for an urgent solution to a longstanding problem in Portuguese society, with strong generational impacts, as some tables in the report show (Portugal, 2008, p. 5). For this reason as there 
is no structural policy on ALE in Portugal, the report seems to have bet heavily on the New Opportunities Initiative to solve problems that have long been a feature of the national economy. This finding becomes clearer when we look at the example of the elderly and of immigrants. All the reports analysed contain references to immigrants, accompanied, in the case of the German and Swedish reports, by data concerning population ageing and specific public provision for this social group (e.g. German and Swedish courses for foreigners). Quantitative data in the Portuguese report indicate the existence of an ageing population and a foreign population (Portugal, 2008, p. 8), although there is no mention anywhere of educational and/or training provision aimed at these individuals.

In line with the objectives established for its public policy on ALE, Sweden's report stresses the role of this domain in the interplay between economic growth and consolidation of democracy, pointing to features of the modernisation and social control and democratic and emancipatory models. In this regard, the report cites the Education Act Chapters 1-9 when it states that,

"The activities within the national adult education system shall be structured in accordance with fundamental democratic values. Each and every person who is active within that school system shall promote respect for the intrinsic value of every human being and for our common environment" (Sweden, 2008, p. 9).

In connection with the consolidation of democracy through the stated purposes, special emphasis is given to the individual, particularly the personal aspect of life in society, though the collective aspect of individual action is not ignored, i.e. with respect to social differences. Thus it says that, "Adult education should also contribute to providing the individual with opportunities for growth and development and reducing gaps between groups in society" (Sweden, 2008, p. 4).

In the report, state action is addressed relative to the individual dimension, particularly when it says that it is responsible for this task of promote opportunities for individuals to develop learning in a variety of times and contexts. For this reason, it mentions principles that entities locally entrusted with implementing the public provision must respect, such as educational flexibility (particularly in methods and information and communication technology) and favouring conditions for learning to continue throughout life. It also reinforces the idea that these principles must meet the interests, needs and abilities of individuals (Sweden, 2008, p. 4), particularly those at greatest educational disadvantage. As it says, ALE is,

"Primarily to those who have received the least education shall here be given an opportunity to strengthen their position in working life and in cultural and political life" (Sweden, 2008, p. 8). 
The Swedish report also highlights the importance of gender equality in the public provision as well as the valuing of knowledge acquired through experience, through validation. It also stresses the importance of ALE in integrating individuals with special needs, including immigrants who can attend different educational activities about Swedish culture and language, organised by the municipalities and publicly funded (Sweden, 2008, p. 10).

It is within priorities that focus mostly on the subjects, according to a humanistic view of education, which can be taken as the characterisation of adult participation in ALE. While, in the German report, increased attendance of ALE activities is particularly linked to the intervention of the Länder whose priority is to facilitate access and increase participation, in the Swedish report another factor seems to contribute to participation levels that are already high compared with those of other countries: the range of provision open to people, including basic education, upper secondary education, supplementary education, municipal education for adults with learning disabilities, Swedish tuition for immigrants, independent supplementary education, advanced vocational training, distance education provided by the Swedish Agency for Flexible Learning as well as folk high schools and study circles (Sweden, 2008, pp. 16-20).

Thus, in Sweden, the call for participation is made in the context of diversification of educational provision, both formal and other non-formal. The need for ALE to meet the interests, motivations and needs of the individuals is highlighted at various points throughout the document, and these may or may not be linked to problems related to employment and work, depending on the principles of the democratic and emancipatory model.

One cannot help but notice that, to add to the range of provision available in Sweden, the report also highlights the 1997 Adult Education Initiative, designed to improve the skills of the workforce, particularly in the case of social groups with poorer skills. As with the political priorities identified for this country, this programme also seeks to combine several objectives:

"The initiative has had four vital perspectives - the renewal of labour market and education policies, more equitable distribution and increased economic growth" (Sweden, 2008, p. 19),

and for this reason it accentuated the role of ALE in economic development and human resources management.

\section{Organisational and administrative dimensions}

It is in the organisational and administrative areas that aspects that fall into the policy models of modernisation and social control and human resources 
management in all countries. In the German report, national public policies are defined by the Federation and, in an effort at decentralisation, (Germany, 2008, p. 158), they are implemented by the Länder. There, the State, through the Federation and the Länder, has "the responsibility for continuing education (...) through legal rules and the earmarking of appropriate financial resources" (Germany, 2008, p. 243). The decentralised nature of ALE public policy depends on strong educational management procedures, particularly in the case of private organisations and those public sector adult education ones that have to apply through a tender process (Germany, 2008, pp. 204-209). As responsibilities are transferred to levels closer to the people and entities that promote ALE locally, there are worries about the control and the quality of educational provision, because the number and variety of organisations involved in public provision should be taken into consideration. As is emphasised in this document, a

“(...) reporting system [was] set up for the long term and designed to produce information on all aspects of the education system every two years in future." (Germany, 2008, p. 206).

While the Länder have important responsibilities for ALE public policy, many tasks are carried out by non-state entities. These entities differ in terms of size, internal structure, legal status, the goals that guide their actions, the activities and projects they implement and the participants involved. Now, these various education providers have been accompanied since the 1980s by the construction of an education market. As it is said in this report, "Commercial continuing education market has become increasingly established" (Germany, 2008, p. 176) as a result of a fall in public funding given that the last decade has seen "clear falls in the subsidies provided by the Länder for continuing education”(Germany, 2008, p. 167).

Consequently, the implementation of these public policies is accompanied by various evaluation and quality control mechanisms, including evaluation studies for different programmes and provision, impact surveys, work on the quality of ALE activities and programs as well as the certification system (Germany, 2008, pp. 205-206). These works are used by entities that promote ALE so that they can improve the efficiency and effectiveness of their education proposals in line with the public policy models of modernisation and social control and human resource management.

The Portuguese report also highlights the role of the state in implementing the ALE policy through the intervention of central government entities, such as the ministries of education, labour and solidarity, and the National Agency for Qualification (ANQ), which, as it says, coordinates and controls the activity of 457 local centres. Regarding these centres, the report notes the rapid expansion of these centres since 2000, when six were set up, further emphasising the urgent 
need of results. These centres should concentrate on participants who are "poorly qualified" and already working, fostering their employability so that they can overcome "their precarious situation due to their low level qualifications" (Portugal, 2008, p. 10). It also indicates that these centres can be accommodated in very diverse entities, from general education school organisations, vocational training centres, non-profit organisations and civil society, business, professional, labour and sectoral agencies, etc. (Portugal, 2008, p. 11).

If the purposes assigned to centres that differ so widely are legitimate, given the characterisation of the education circumstances of the Portuguese population described in the report, the goals that the New Opportunities Initiative intended to be achieved by 2010 , the year that the programme should be ended, seem ambitious. This programme was intended "to qualify 1,000,000 active workers by 2010 " (Portugal, 2008, p. 3), which corresponds to about 10per cent of its population. In greater detail, the Portuguese report aims at the certification and qualification 350,000 individuals at the compulsory education levels of 9 and 12 years, attendance of adult education and training courses, and 650,000 individuals certified and qualified through the recognition of prior learning (Portugal, 2008, pp. 10-11).

To achieve these results, taking into account the involvement of so many different bodies, a system to control and monitor the public provision was set up, called the "Integrated System for Management of the double certification training provision" that should contribute to the " efficacy, efficiency and quality assurance" of the ALE system built within the New Opportunities Initiative (Portugal, 2008, p. 11). This system is given some attention in the report, together with other mechanisms such as the New Opportunities Centres Quality Charter that "aims to improve and promote quality assurance" in the recognition of prior learning processes. The monitoring meetings held with all of those involved in the public provision (Portugal, 2008, p. 23), and also the external evaluation of the New Opportunities Initiative developed by the Portuguese Catholic University were also referred. Regarding this assessment, it states that,

"The aims of the evaluation study [the external evaluation study of the New Opportunities Initiative] are to assess the political measure, its intervention structure and the procedures implemented, as well as the quality of the outputs and the satisfaction level of the adults involved. These studies aim also to produce or improve tools to assess permanently the system procedures out outputs" (Portugal, 2008, p. 23).

Thus, the control and evaluation mechanisms mentioned in both the German and Portuguese reports suggest the possibility of entities competing for funds, which implies the adoption of principles of modernisation and social control model, but, above all, of human resources management model. The situation is quite different 
in the Swedish report. This document highlights state intervention and, above all, intervention by the municipalities under the provision of formal education. Thus,

"The division of responsibilities is based on the main principle that the Riksdag and the Government should control educational activities by defining national goals, while central authorities, municipalities and the organisers of the different institutions are responsible for ensuring that educational activities are implemented in line with the legislative framework and that the national goals for the education are achieved." (Sweden, 2008, p. 8).

It goes on,

"Instruments used to promote adult education include: Setting up overall goals for publicly funded adult education, Regulating the rights of adults to education and the obligation of educational providers, Wide-ranging financial support to municipalities, folk high schools and adult study associations and educational organisers, A generous system for study support to adults" (Sweden, 2008, p. 4).

These policy guidelines encourage the achievement of establishing the right to education, i.e. formal education, which encompasses the provision of basic adult education, upper secondary adult education and supplementary education, education for adults with learning disabilities and tuition for immigrants. This commitment chimes with the principles of the modernisation and social control model. In addition, the scope of action of the municipalities covers: the obligation to offer a range of provision, in the form of courses and it should eventually be possible to call on non-municipal entities to do this, if municipalities lack the conditions; facilitating access and thus stimulating the participation of all, regardless of gender, age, and level of education; the development of courses that match the demand for education and the needs of individuals, such as immigrants aged over 16, for whom municipalities must offer Swedish courses within three months of the need of these individuals to attend such courses being known, so that they can learn the language and culture and become socially and professionally integrated as quickly as possible (Sweden, 2008, pp. 9-11).

In order to further involve the municipalities in educational provision, the same report also indicates that,

"A major part of liberal education is closely connected with popular movements and other organisations that are either members of study associations or connected with folk high schools. Unlike other educational institutions, folk high schools and study associations are not required to follow centrally established curricula." (Sweden, 2008, p. 11).

We can see, therefore, that apart from state action through the municipalities Swedish public policy tasks civil society with carrying out non-formal education activities. The priorities of these entities are in line with the values and principles 
established by ALE policy and must strive to "bridge educational gaps" by targeting people "who are disadvantaged educationally, socially and culturally" such as those of foreign descent, the physically or mentally disabled and the unemployed (Sweden, 2008, p. 11). Furthermore, these priorities allow the individuals who attend these activities to take part in setting objectives and content, thus meeting their expectations and needs. For these reasons, as stated in the Swedish report, the actions implemented by the folk high schools and study associations include a significant range of activities (music, theatre, health promotion, etc.), with about 300,000 courses being held per year, involving a very large number of adults (about 1.5 million).

Given the range of entities involved in ALE provision, the emphasis placed by the Swedish report on the systems for monitoring and evaluating the public provision relate the increased autonomy granted to local entities with increased responsibility and accountability. The public provision is monitored and evaluated via: i) inspections carried out by state agencies; ii) national and international evaluations that result in the presentation of public reports on a regular basis (Sweden, 2008, p. 21). In this regard there is a focus on monitoring and evaluation carried out by the state through various strategies, noticing the relationship between the results obtained in these studies and state funding to be granted to public provision. These quality control mechanisms endeavour to increase the responsibility of the local actors (notably promoters and adult educators), in line with the model of modernisation and social control, and they can also support an emerging competitive system of entities promoting ALE, depending on the human resources management model.

\section{Conceptual elements}

The programmes and activities described in the German report are as diverse as the entities that are involved in ALE. This document indicates general education, cultural and civic initiatives. These actions include second chance formal education, language learning, courses related to information and communication technology, education initiatives for citizenship, and other cultural, health promotion and environmental protection education actions. Other general, civic and cultural education activities can be found in adult education centres. These may include content such as information and communication technology, language learning and also broach related topics such as health (Germany, 2008, pp. 181-185).

This variety could suggest principles of the democratic and emancipatory public policy model. However, the importance given to vocational training actions should be noted: initial; continuous, which is the most significant in terms of the 
number of programmes; retraining; further development. This is in keeping with the principles of the modernisation and social control model, and with human resources management, too, because companies are the entities with the most ALE provision and highest volume of participation involved (Germany, 2008, pp. 180-181). In the same vein, this report states that the promotion of education and lifelong learning with objective to equip

"People with the tools they need for mastering the challenges and using the opportunities of globalization (...) Lifelong learning must become a matter of course in our rapidly changing society. No one should be left behind in the process of modernisation because of inadequate opportunities for education and training. (...) We must continue our efforts (...) to gear adult education programmes to the interests of people and the demands of a changing economy" (Germany, 2008, p. 5).

It is also indicated in this report that,

"(...) there is a need for greater responsibility and civic commitment on the part of the individual. This is an area in which continuing education can help to inform people, open up prospects for action and promote the development of positive values." (Germany, 2008, p. 161).

We find an emphasis on economic development, while individuals are given responsibility for building their paths of education and training. This trend fits with the legislation recently adopted in this country in relation to ALE that seeks to coordinate with the EU guidelines, influenced by principles of human resources management (Field, 2006 and Milana \& Holford, 2014, among others). This coordination between German ALE public policy and EU guidance has been helped by an extended national consultation on the Memorandum on Lifelong Learning, which took place in 2000/2001, the Fourth Recommendation on Continuing Education, 2001, the adoption of the Strategy for Lifelong Learning in the Federal Republic of Germany, 2004 (Germany, 2008, pp. 153-156). These documents show us the building of a "comprehensive system of lifelong learning" (Germany, 2008, p. 152), in an "information and knowledge society", in "Europe as the world's most competitive economy". This is the route by which, in addition to programmes that favour sectors such as vocational training and basic education, in harmony with strategies linked to EU purposes, others are linked to reinforcing "the concept of individual responsibility and self-direction on the part of the learner" and "to improve the ease of movement around the education system and to improve the link-up between all areas of education (through, for example, modular courses and the recognition of skills" (Germany, 2008, p. 152).

The connection of public policy on ALE to EU guidance is even more evident in the Portuguese report. Although both the German and Swedish reports contain 
references to learning throughout life, to build a society and an economy based on knowledge, as well as more consistent keywords with discourses that propagate the EU guidance, it is in the Portuguese report that the presence of such ideas is most evident. This is particularly noticeable in the narrow understanding of ALE, limited to education (formal) and training (through obtaining vocational qualifications) that lead to the development of economically useful knowledge and skills. As stated in that report,

"Over the last decades, Portugal has made a significant effort to qualify the general population, and the adults in particular, so as to make up the lag separating us from the other developed countries. (...) Being insufficient and slow the recovery, the actual Government decided to do more, better and deeper to overcome the low levels of education and qualification of the Portuguese population and stated in 2005 the New Opportunities Initiative as a national strategy within the scope of the National Employment Plan and the Technological Plan" (Portugal, 2008, p. 2).

Two public provisions are so named in this report, i.e. the recognition of prior learning and adult education and training courses. These two provisions cover basic education equivalent to 9 and 12 years of compulsory schooling, and vocational training that leads to professional qualification (Portugal, 2008, pp. 10-11). Informal education is also rated highly, through the recognition of prior learning, which is expected to yield the largest number of certifications by 2010 .

This focus can also be noticed in the funding of ALE under the New Opportunities Initiative. In this context, support for the development of public provision had two sources, namely, the EU, through the European Social Fund, 75per cent of the total funds, and 25per cent from Portugal, provided through the national budget. The data show a progressive increase in funding of this sector since the beginning of the 2000s (Portugal, 2008, p. 14).

The German and Swedish reports both indicate a significant number of ALE activities, but there is a particular emphasis on liberal adult education. In this case, the Swedish report says that this type of ALE is carried out by the folk high schools and study associations, with a view to the participation of "all groups in society" covering "a broad range of subjects at various levels" (Sweden, 2008, p. 6). These actions have no pre-defined curriculum, given that they aim to meet the demand for liberal education, not an educational and pedagogical structure or established recipients, and can therefore be attended by all those who wish to make. In this regard, it states that,

"The freedom to determine own activities and educational profile affords each folk high school and study association considerable scope to design and tailor its courses to suit a range of target groups." (Sweden, 2008, p. 11). 
In addition, it highlights the concern to tailor the provision to the needs and interests of the participants, encouraging them to participate, particularly through financial support. This is why they are supported by state funds offers where,

"People are given the opportunity to influence their situation in life and take part in social development. Democracy is to be strengthened and developed. Interest in culture is to be broadened and participation and individual's own creativity is to be furthered" (Sweden, 2008, p. 11),

in line with the principles of the democratic and emancipatory model.

\section{Towards a comprehensive interpretation}

As noted in the above discussion, the studied reports described programmes and actions that contained elements of the three public policy models, albeit with varying degrees of focus on the characteristics of each model.

All the reports are committed to the development of basic education policies, including initiatives for second chance adult education, basic education and learning German and Swedish language and culture in an effort to ensure all the individuals from these countries or living in them, as in the case of immigrants, have the knowledge and basic skills for social, civic, cultural, political and economic intervention. Although included in different formal education programmes, in the cases of Germany and Sweden, or recognition of prior learning, in the case of Portugal, the country reports analysed for this article provided data that make it possible to fit these provisions into modernisation and social control policies.

In addition, it was also possible to ascertain the (increasingly strong) presence of a market, largely through developing programmes aimed at modernising the economy, in which significant emphasis is ascribed to the provision designed, achieved and evaluated by vocational training departments of companies, sectoral entities, for-profit organisations that invigorate training and retraining activities. These actions are mentioned in all the reports, revealing characteristics of the human resources management policy model and differing in relation to the public policy purposes and goals. In Germany, these activities were linked to the effort to qualify labour to work in certain economic sectors that offered the greatest potential for economic growth and increased productivity, while Portugal's commitment to these principles stemmed from the need to converge the national economy as part of a major restructuring, from its opening up since the 1980s and from the relatively low rates of education of its population. Although both countries were concerned with economic development, in fact these concerns were expressed in different purposes and in distinct programmes, as we have seen. In the case of Sweden, the characteristic elements of the human resources management model 
were less evident, although some recent programmes relating to lifelong learning and keeping the Swedish economy one of the most competitive in the world, and concern for the validation of knowledge acquired throughout life were situated in this area.

But it was clear that more of the initiatives in Sweden required the involvement of civil society, including actions to promote democracy, equal opportunities, social justice and civic participation, than are mentioned in the German and Portuguese reports. Thus, except for the Swedish report, the characteristics of the democratic and emancipatory public policy model were those hardest to find in the texts in question contrary to the strong tradition of adult education, of challenge, resistance, social change and emancipation. This absence was particularly evident in the Portuguese report, due to the features of the programme implemented after 2005, the New Opportunities Initiative.

The inclusion of elements of various public policy models in the public policies of these countries was also evident, indicating intersections and hybridism. In this context, there was clear interaction between elements of the modernisation and social control policy model and the human resources management model in the organisational and administrative dimensions, as well as the policy and administrative guidance in all the countries studied, most clearly in Portugal and Germany. This interaction occurs in the context of societies in which we see strong changes in the economy, more and more computerised and marked by new forms of capitalist accumulation, in which workers need new knowledge and skills. Where we see interaction between elements of the modernisation and social control and democratic emancipatory models, this link was most visible in the policy priorities established in the Swedish report and less so in the German one. It seems that the belief that promoting this area can contribute to the consolidation of democracy, social justice, equal opportunities and solidarity still prevails at the level of the values defined for public policy on adult education. It is also in the conceptual elements, especially regarding the defence of the variety of adult education practices, the entities promoting educational provisions and the (individual and institutional) actors involved in this area, that there has been an intersection of elements more characteristic of the modernisation and social control and democratic emancipation models, particularly in the Swedish report. This variety to meet the needs, interests and motivations of adults and tried to sustain adult participation in programmes promoted in public policies.

It was more difficult, however, to find connections between all the models indicated in this article, i.e. modernisation and social control, management of human resources and democratic and emancipatory, in the areas chosen for this analysis. 
This situation is indicative of the dwindling importance that policies relating to redistribution, social justice and even the consolidation of democracy have in European countries, particularly those that were studied through these reports. The exception to this is Sweden which, albeit with less force, still maintains policies related to democratic education and to personal and social development in a society whose benchmark values are the consolidation of democracy and the promotion of social justice. This country's report contains many instances of an effort to coordinate very different elements, characteristics of the three analytical models, thus reflecting the importance that the history of adult education still has in the educational provision available to adults.

\section{Supra-national influence, national features and governmental priorities}

The analysis of the selected documents revealed different policies, in which the dissimilarities were related to the search to respond to problems and contextual and/or cyclical needs. Here, adult education policies in the countries studied are still marked by difference, which derives mainly from state intervention, the market and civil society of a national nature. However, the similarities between the policies of the countries concerned were particularly evident. In this context, we draw attention to frequent references to the mega level, especially mentions of the EU and programmes such as the European Social Fund, intended mainly for the development of vocational training and qualification of labour. Apparently missing is UNESCO, which has played an important role in consolidating adult education as a field of reflection and even promotion of intervention programmes. Thus, references to the $\mathrm{EU}$ arise from the various actions that the countries under consideration implemented with European funding under the guidance of this supranational actor. In fact, the macro level, national in nature, still retains a strong presence in the reports. Even assuming that transnational influences affected, for example, leading economic enterprises such as the automotive sector, where innovation in vocational training served as a model for many other sectors of the economy, or, as happened with the international intervention of a development agency, government or non-government of Sweden and Germany in the 1960s and 1970s, the programmes implemented were notable for their national elements, and therefore differed from country to country in terms of cyclical and contextual elements. But, when producing policy guidelines and submitting funding programs to promote lifelong learning, the EU designed an effective political strategy of convergence of national practices in adult education, very targeted, however, at the economic development of certain sectors considered innovative and pivotal 
to building a highly competitive economic zone in the global market. In this context, in which the characteristics of the human resources management model are particularly evident, state intervention at the macro level seems increasingly limited to basic education actions and the design and monitoring of regulatory and control mechanisms. Here, the state seems to take on more management functions, thereby relinquishing the political functions that particularly characterised the " 30 glorious years" in the framework of the social contract and the enshrinement of training and education as basic social rights of workers and citizens. In this regard, while the three reports still feature the strong presence of the state, this relates more to the monitoring and evaluation of the provisions offered by this sector than to the public provision. While this circumstance is related to the fact that these are official documents, it is also true that the intervention of this actor seems to be in clear decline, particularly with respect to the state institutional provisions geared to adults. And here there appears a contradiction between the established government priorities, which still feature democratic and emancipatory elements, and the programmes and activities implemented that highlight the connection between the modernisation and social control and human resources management models that only studies at the meso and micro levels can clarify. But, as already mentioned, that task is beyond the scope of this article.

\section{References}

Andersson, P. \& Fejes, A. (2005): Recognition of Prior Learning as a Technique for Fabricating the Adult Learner: A Genealogical Analysis on Swedish Adult Education Policy. In Journal of Education Policy, 20, 5, pp. 595-613.

Barros, R., Guimarães, P. \& Lima, L. C. (2012): Comparative Issues in Public Policies on Representations of Adult Learning and Education: Reports to CONFINTEA VI of European Union Countries. Paper Presented at the Inaugural Conference of the ESREA Network on 'Policy Studies in Adult Education'. Nottingham.

Bélanger, P. \& Federighi, P. (2001): Analyse Transnationale des Politiques d'Éducation et de Formation des Adultes. La Libération Difficile des Forces Créatrices. Paris.

Esping-Andersen, G. (1990): The Three Worlds of Welfare Capitalism. Cambridge.

Field, J. (2006): Lifelong Learning and the Educational Order. Stoke-on-Trent.

Finger, M. \& Asún, J.-M. (2001): Adult Education at the Crossroads. Learning our Way Out. London.

Giddens, A. (1999): Para uma Terceira Via. Lisboa.

Griffin, C. (1999a): Lifelong Learning and Social Democracy. In International Journal of Lifelong Education, 18, 5, pp. 329-342. 
Griffin, C. (1999b): Lifelong Learning and Welfare Reform. In International Journal of Lifelong Education, 18, 6, pp. 431-452.

Guimarães, P. (2011): Políticas de Educação de Adultos em Portugal (1999-2006). A Emergência da Educação para a Competitividade. Braga.

Guimarães, P. (2013): Reinterpreting Lifelong Learning: Meanings of Adult Education Policy in Portugal, 1999-2010. In International Journal of Lifelong Education, 32, 2, pp. 135-148.

Keogh, H. (2009): The State and Development of Adult Learning and Education in Europe, North America and Israel. Regional Synthesis Report. Hamburg.

Larsson, S. (1998): Defining the Study Circle Tradition. In A. Bron, J. Field \& E. Kurantowicz (eds.): Adult Education and Democratic Citizenship II. Kraków, pp. $50-70$.

Larsson, S. (2001): Les Cercles d'Études et la Démocratie en Suède. In Éducation Permanente, 149, pp. 231-256.

Lattke, S. (2008): Educação de Adultos na Alemanha: Desenvolvimento Histórico e Desafios Actuais. In Aprender ao Longo da Vida, 9, pp. 41-46.

Law, M. (1998): Market Oriented Policies and the Learning Society: The Case of New Zealand. In J. Holford \& P. Jarvis \& C. Griffin (eds.): International Perspectives on Lifelong Learning. London, pp. 168-179.

Lima, L. C. (2005): A Educação de Adultos em Portugal (1974-2004). In R. Canário \& B. Cabrito (eds.): Educação e Formação de Adultos. Mutações e Convergências. Lisboa, pp. 31-60.

Lima, L. C. (2013): Intermitencias Políticas de la Educación Permanente: Del Deficit de Cualicación a la Promoción de la Ciudadanía. In M. Aparicio Barberán, M. \& I. Corella Llopis (eds.): Educación Permanente y Ciudadanía. Xàtiva. València, pp. 19-42.

Lima, L. C. \& Guimarães, P. (2011): European Strategies in Lifelong Learning: A Critical Introduction. Opladen \& Farmington Hills.

Lima, L. C. \& Guimarães, P. (2015): Portugal: Policy and Adult Education. In T. Corner (ed.): Education in the European Union. Pre-2003 Member States. London, pp. 245-263.

Milana, M. (2014): UNESCO, Adult Education and Political Mobilization. In Confero, 2, 1, pp. 73-107. DOI: 10.3384/confero.2001-4562.140604 ${ }^{\text {a }}$ (accessed: 03.04.2015).

Milana, M. \& Holford, J. (eds.) (2014): Adult Education Policy and the European Union. Theoretical and Methodological Perspectives. Rotterdam.

Mishra, R. (1995): O Estado-Providência na Sociedade Capitalista: Estudo Comparativo das Políticas Sociais na Europa, América do Norte e Austrália. Oeiras. 
Norbeck, J. (1979): Formas e Métodos de Educação de Adultos. Braga.

Nuissl, E. \& Pehl, K. (2000): Portrait Continuing Education Germany. Bielefeld.

Rappke, H.-D. (2001): L'Éducation des Adultes en Allemagne depuis 1945: Héritages et Innovation. In Éducation Permanente, 149, pp. 185-196.

Rubenson, K. (1994): Recurrent Policy in Sweden: A Moving Target. In P. Bélanger \& E. Gelpi (eds.): Lifelong Education. Hamburg, pp. 245-256.

Rubenson, K. (2004): Lifelong Learning: A Critical Assessment of the Polítical Project. In P. Alheit, R. Becker-Schmidt, T. Gitz-Johansen, L. Ploug, H. Olesen \& K. Rubenson (eds): Shaping an Emerging Reality. Researching Lifelong Learning. Roskilde, pp. 28-45.

Sanz Fernández, F. (2006): As Raízes Históricas dos Modelos Actuais de Educação de Pessoas Adultas. Lisboa.

Vallgårda, H. \& Lima, L. C. (1985): As Escolas Superiores Populares e a Educação de Adultos. In Jornal da Educação, 85, pp. 26-27.

Vallgårda, H. \& Norbeck, J. (1986): Para uma Pedagogia Participativa. O Círculo de Estudo e o Guia de Estudo. Braga.

UNESCO national reports analysed. (Retrieved from http:// http://www.unesco. org/en/confinteavi/national-reports/europe-and-north-america, on April 2011).

Germany (2008): Report from Germany: CONFINTEA VI - Bericht Deutschland. The Development and State of the Art of Adult Learning and Education (ALE).

Portugal (2008): Report from Portugal: The Development and State of the Art of Adult Learning and Education (ALE) - National Report of Portugal.

Sweden (2008): Report from Sweden: 6th International Conference on Adult Education (CONFINTEA VI). National Report on the Development and State of the Art of Learning and Education (ALE). 